\title{
KORRÓZIÓÁLLÓ VASTAG LEMEZ EGY OLDALRÓL TÖRTÉNŐ HEGESZTÉSE
}

\section{STAINLESS STEEL PLATE ONE SIDE WELDING}

Felvári Bálint, ${ }^{1}$ Dunavölgyi Dávid, ${ }^{2}$ Kuti János ${ }^{3}$

Óbudai Egyetem, Bánki Donát Gépész és Biztonságtechnikai Mérnöki Kar, Gépészeti és Biztonságtudományi, Budapest, Magyarország

${ }^{1}$ felvari.balint@bgk.uni-obuda.hu

${ }^{2}$ dunavolgyi.david@bgk.uni-obuda.hu

${ }^{3}$ kuti.janos@bgk.uni-obuda.hu

\begin{abstract}
The authors in this research investigated a cost-effective welding setup for stainless steel following the industrial trends. Ajustments, movements and tests can be avoided during plate welding by welding the piece from one side. During the research, the applied layout is investigated, any deformities that may be caused, and whether it can maintain the inter-row temperature.
\end{abstract}

Keywords: welding, plate, stainless steel.

\section{Összefoglalás}

Kutatásukban a szerzők az ipari trendeket követve egy költséghatékony hegesztési elrendezést vizsgáltak meg, korrózióálló acél esetén. A vastag lemezek hegesztése során felmerülő beállítások, mozgatások, hegesztés közbeni vizsgálatokat kerüljük el azzal, hogy egy oldalról hegesztjük a darabot. A kutatás során az alkalmazott elrendezésnek a hatásait vizsgálták meg, milyen deformációkat okoz, tartható-e a sorközi hőmérsékletet?

Kulcsszavak: hegesztés, vastag lemez, korrózióálló acél.

\section{A kutatás célkitűzése}

Kutatásunkban azt vizsgáltuk, hogy egy ausztenites korrózióálló vastag lemezt meg lehet-e hegeszteni kielégítő módon szűkített V-varrattal egy oldalról. Az egyoldali hegesztéseknek számos előnye van, ugyanakkor a kisterületen bevitt nagy energia miatt nagy deformációt okoz [1, 2].

\section{Kísérlet elrendezése, kivitelezése}

\subsection{Darabok megmunkálása}

A minták valamilyen termikus vágási eljárással kerültek kimunkálásra, így az oldaluk utómunkálatokra szorult. A munkálatok megkezdése előtt tisztázni kellett a hegesztés kialakításához szükséges geometriákat, illetve az azt vizsgáló folya- matok segédmegmunkálásait (gondolok itt a termoelemek elhelyezésére). A szabvány által előírt, szűkített V-varrat kiképzését lemezenként $15^{\circ}$-ra készítettük el egy gyalu segítségével.

\subsection{Termoelemek elhelyezése, furatok elkészítése}

A termoelemes mérés segítségével meghatározható a hőterjedés, illetve a varrat közvetlen közelében mért hőmérsékletek, és ezáltal akár a metallurgiai folyamatok [3]. Ebből kifolyólag nagyon nagy szerepe van annak, hogy a mérőegységeket hova és hogyan helyezzük el a darabon. A mi fő célunk a termoelemek elhelyezésével a sorközi hőmérsékletek pontos meghatározása volt, illetve hogy a jövőben tudjunk egy komoly hőterjedési modellt alkotni $[4,5]$. 


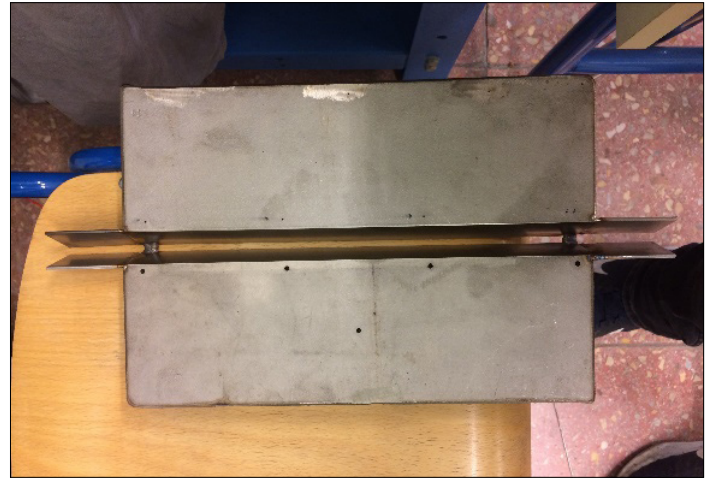

1. ábra. A hegesztési próbatest előkészítve összefüzve

\section{3. Összeállítás}

A darabok leélezése és kifúrása után az összeállítás maradt hátra. A két darabot a leélezésnél egymásnak fordítva, öt milliméter hézagot hagyva a kettő között, két füzővarrattal rögzítettük (1. ábra). A darabok két végén kifutást és befutást alkalmaztunk. Ennek főbb oka, hogy a hegesztési ív már a segédlemezeken létrejöjjön az ömledékkel együtt, és az alapanyagba belépve már stabilan haladjon. A gyökvarrat folytonos kihegesztését kerámiatámasszal segítettük.

\subsection{Hegesztőautomata összeállítása és konfigurálása}

A referenciamérést egy egyedi roboton végeztük el, melyet az egyetemen fejlesztettünk. A hegesztő automatánk kezelőfelülettel, a végálláskapcsolók pozicionálásával és a hegesztőfejet befogadó berendezés beállításával segíti a pontos, reprodukálható hegesztési helyzetet. Az automata és az EVM hegesztőgép összekötetését egy átalakított munkakábellel oldottuk meg. A robot vezérlőegységébe belekötöttük a kábel nyomógombját, ami így aktiválta az áramforrást az adott időpillanatban, és le is állította azt, amikor kellett. A robot kezelőfelülete egy arduinó segítségével működött. A panelon nyomógombok segítségével állítható a hegesztés sebessége $\mathrm{cm} /$ méter léptékben. A felkonfigurálás után csak a végálláskapcsolókat kellett pozícióba hozni a munkadarabhoz képest, ezt követte a hegesztő áramforrás beállítása és felszerszámozása [6].

A hegesztőgép egy EVM Taurus Synergic-típusú berendezés, amely kiválóan alkalmas „komplikált” folyamatok lebonyolítására [7]. A gép elektronikája tartalmaz úgynevezett JOB-okat, amelyek a gyártó által felprogramozott tartományokban tartják a hegesztési paramétereket, így nekünk a gép katalógusából kellett kiválasztani a hegesztőeljárás típusát, esetünkben MIG (Metal Inert Gas - semleges védőgázas, huzalelektródás ívhegesztés), a hegeszteni kívánt anyagminőséget (ausztenites korrózióálló acél) és a JOB-ot. A gép elektronikus beállítása részben megtörtént, innentől kezdve csak az áramerősség növelését vagy csökkentését kellett állítanunk a beolvadás és varratok, varratképek szerint. A hegesztéshez kevert gázt választottunk, a Linde Corgon gázkeverékét. A corgon egy fantázianév, ez az öszszetétel $18 \% \mathrm{CO}_{2}$ és $82 \%$ Ar-t tartalmaz, szabvány megnevezése „ISO 14175 -M21 - Arc - 18”. A gázt egy reduktoron keresztül kötöttük a gépbe, habár a gép és reduktor segítségével be lehet állítani a gáz áramlási mennyiségét, a valós értéket a hegesztőpisztoly végéhez illesztett rotaméterrel állítottuk be.

Mikor a hegesztés menetét manuálisan végigpróbáltuk, sajnos, észrevettük, hogy a gázterelő nem fér be a lemez kimunkált területébe, ezáltal nagyon hosszú ívhosszt kellene tartanunk, ami az ívzárás folytonosságát, ezáltal a gondtalan ömledékképződés és hegesztési varrat kialakulását hátráltatná, megakadályozná. Emiatt módosításokat hajtottunk végre a gázterelőn. Továbbá a fröcskölésből és gázokból adódó „szennyeződések” letapadását a gázterelőben megakadályozva, kerámiabevonattal láttuk el a komponenst. A kísérlet során a varratsorok hủlése közben ezt a kerámiaréteget többször pótoltuk, illetve tisztítottuk, a gáz gondtalan áramlása és az állandó mennyiség érdekében.

\subsection{Termoelemek bekötése, kalibrálása}

A kísérletet termoelemekkel követtük nyomon, melyeket egy központi adatfeldolgozóba kötött, amelyet csatlakoztattunk egy notebookhoz (2. ábra).

A hegesztést olyan módon hajtottuk végre, hogy minden sor egyre rövidebb lett, $20 \mathrm{~mm}$-re így minden egyes sorból tudtunk egy csiszolatot

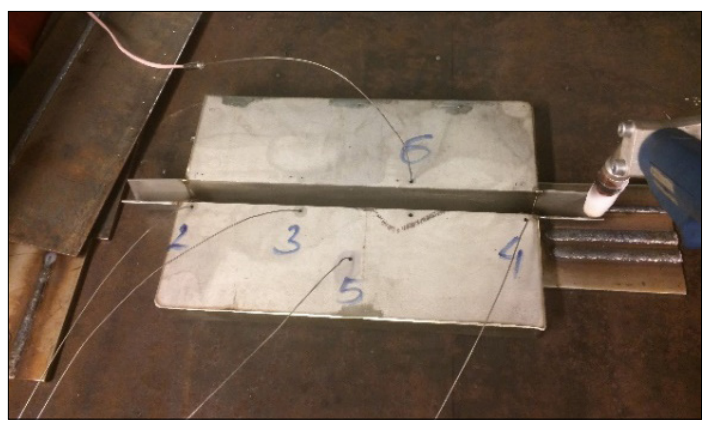

2. ábra. Összeállított próbatest 
készíteni, és megközelítően soronként vizsgálni a hőövezeti zónát és a hegesztési varratokat (a 3. ábra szerint történt a minták kimunkálása).

A metszetek elkészítését egy szalagfürésszel végeztük el, biztosítva a folyamatos hűtést.

\subsection{Minták felülettisztázása}

A ledarabolt szegmensek különböző méretűek és felületi érdességüek voltak, ahhoz, hogy mikroszkóppal a szövetképet elemezni tudjuk, a felületet síkköszörün tovább finomítottuk, majd a csiszolással és polírozással előkészítettük.

A minták maratását KALLING maratószerrel végeztük, amelynek összetétele a következő: $\mathrm{CuCL}_{2}$ $5 \mathrm{~g}$, sósav $100 \mathrm{ml}$, etanol $100 \mathrm{ml}$.

A 4. ábrán látható csiszolaton jól kivehető a varratsorok egymásra épülése, illetve az is, hogy a gyöksor, az alapanyag és a második sor találkozásánál egy gázzárvány található. A legelső sort, azaz a gyököt leszámítva, jól látszik a varratsorok szimmetriája és egyenletessége. A gyökből kivehető, hogy az ív a bal oldali alapanyag felé húzott, így a beolvadás teljesen aszimmetrikus. Továbbá látszik az állandó előtolás és áramerősség is, hiszen a gyökhézag növekedésével a varratmagasság csökkent. Ideális esetben, ez a két érték exponenciálisan nő.

$\mathrm{Az}$ 5. ábra bal oldalán a varratot láthatjuk, amelyben fekete csíkokként megjelenik a delta ferrit. Az oszloposság a hő leadásiránya felé terjed. A varrat és az alapanyag széle között $10 \mu \mathrm{m}$ szélességben kivehető a hőhatásövezet.

A szemcsedurvulás nem jelentős, de a határaikon Cr-karbid kiválás fedezhető fel (6. ábra).

Az alakítás iránya jól kivehető az alapanyagban (7. ábra), ennek oka a bekövetkező mikrodúsulások. Dermedés kezdetén ekviaxiálisak a szemcsék, a sor szélein finomabbak, beljebb durvábbak/nagyobbak. A varratra jellemző az oszlopos és homogén struktúra.

Továbbá érdekesség, hogy a mikrofelvételeken nem, de a keménységmérő mikroszkópjában igen jól látszik a varrat külső és belső szerkezete között a különbség. Kívül durvább, míg beljebb finomabb a szerkezet (8. és 9. ábra).

\subsection{Mért keménységek}

A keménységmérést egy Vickers mikrokeménység-mérővel végeztük el. A mérést $0,2 \mathrm{~kg}$ terheléssel hajtottuk végre. A mintát soronként osztottuk fel, és a következőket mértük: minden sorban háromszor mértük meg az alapanyag és a varrat keménységét. Továbbá szintén háromszor mértük a hőhatásövezetet minden egyes sorban (10. ábra).

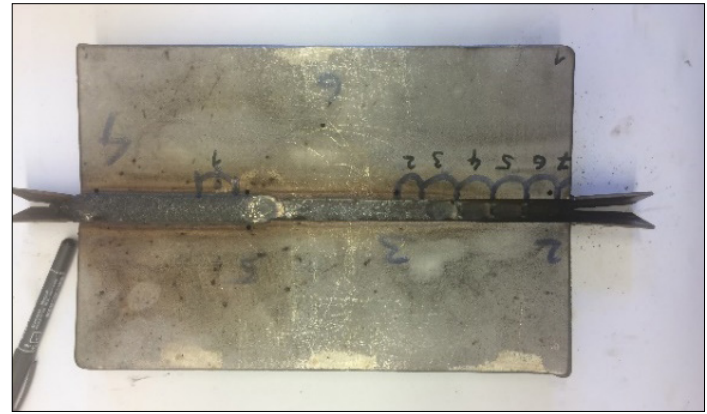

3. ábra. Szelvények kijelölése

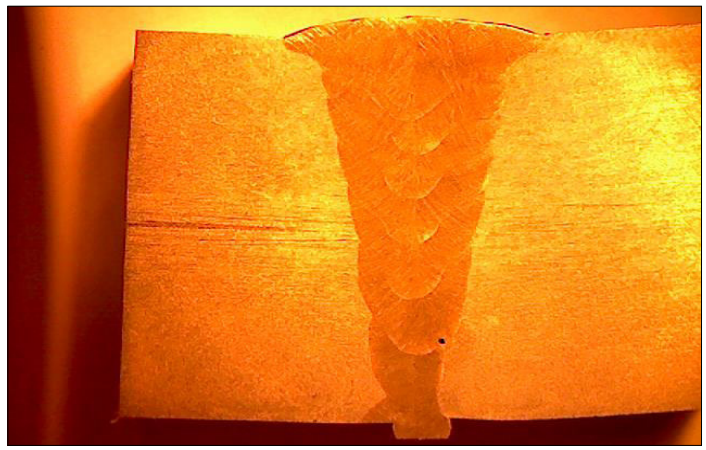

4. ábra. Teljes varratmetszet

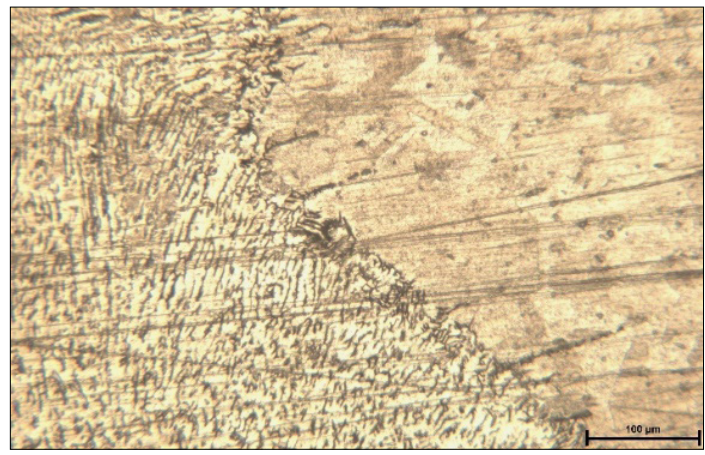

5. ábra. A varrat és az alapanyag

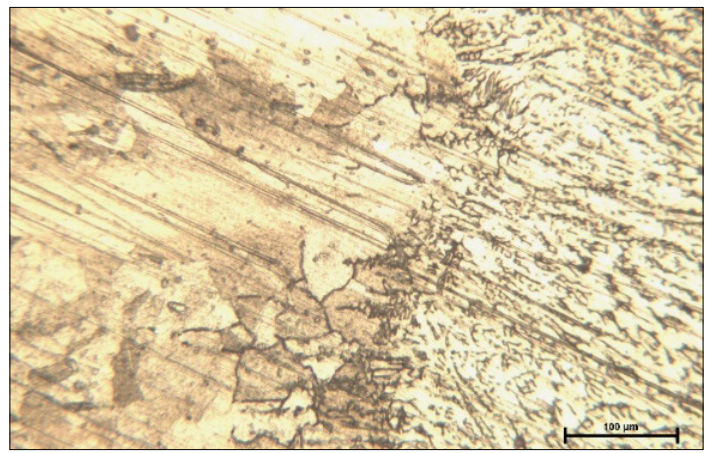

6. ábra. Varrat határán lévö minimális szemcsedurvulás 


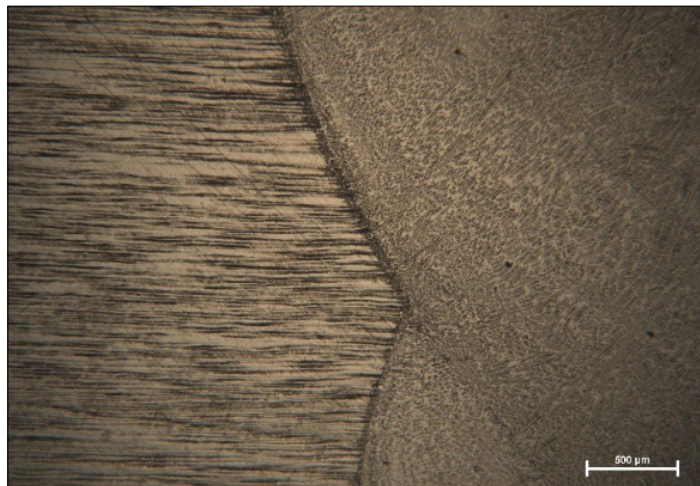

7. ábra. Alakított alapanyag

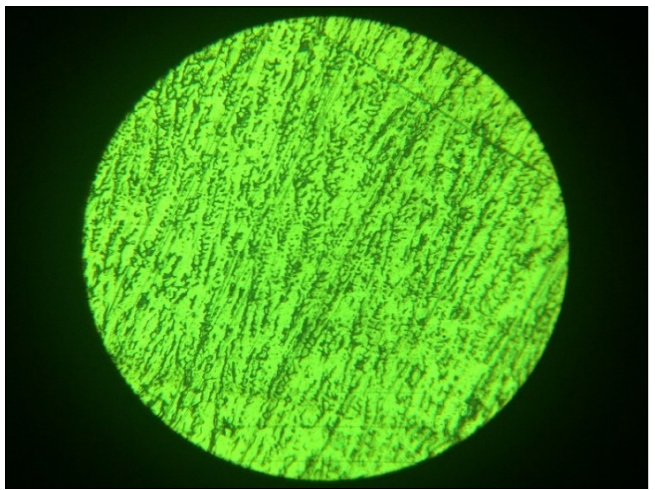

8. ábra. Varrat széle

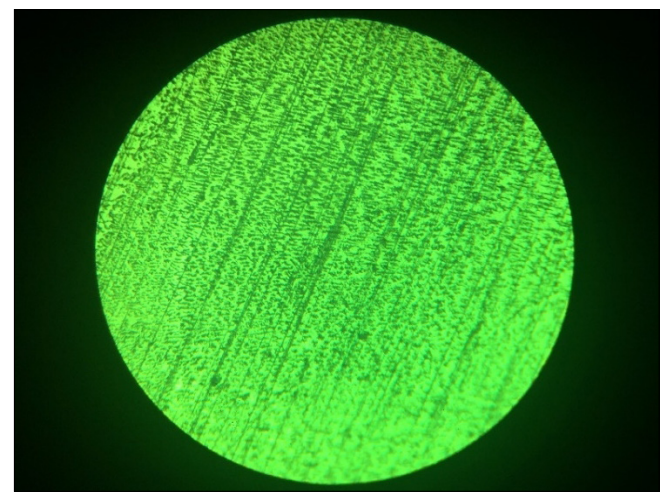

9. ábra. Varrat közepe

\section{3. Összefoglalás}

Mind a keménységmérési eredményekből, mind a szövetszerkezet-vizsgálati eredményekből megállapítható, hogy az egy oldalról történő, szűkített V-varrat hegesztése sikeresen lett végrehajtva. Ugyanakkor a hegesztés hatására a darab jelentősen vetemedett. A kutatás folytatásaként ezt kell kiküszöbölnünk, előfeszítéssel, illetve kisebb energiabevitelü hegesztési eljárásokkal.

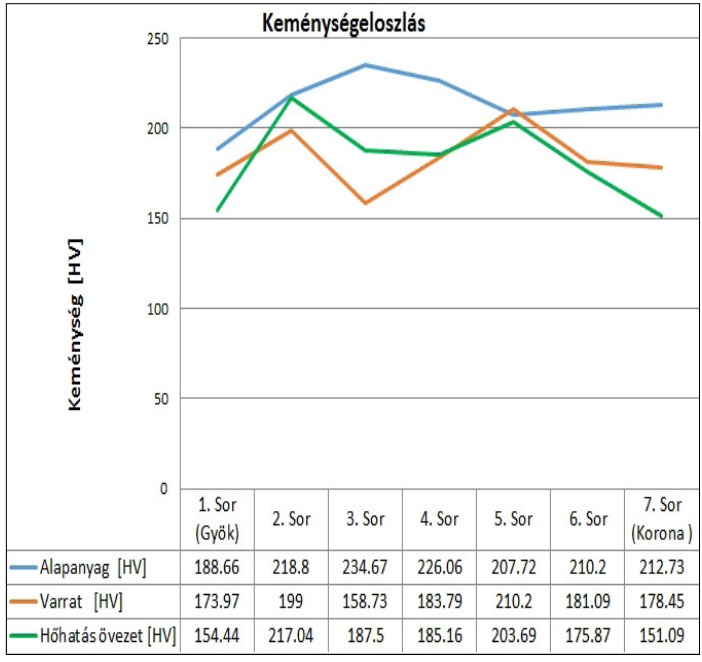

10. ábra. Keménységértékek

\section{Köszönetnyilvánítás}

Szeretnénk köszönetet mondani a magyar államnak és az Európai Uniónak az EFOP 3.6.1.-16.-2016-00010 számú projekt támogatásáért.

\section{Szakirodalomi hivatkozások}

[1] Gáti J.: Hegesztési Zsebkönyv. Cokom, 2003 .

[2] Bagyinszki Gy., Bitay E.: Hegesztéstechnika I. Eljárások és gépesítés. Műszaki Tudományos Füzetek 9., EME, Kolozsvár, 2010.

https://doi.org/10.36242/mtf-09

[3] Bagyinszki Gy., Bitay E.: Hegesztéstechnika II. Berendezések és mérések. Műszaki Tudományos Füzetek 10., EME, Kolozsvár, 2010.

https://doi.org/10.36242/mtf-10

[4] Cloos: Rapid Weld - That's what efficiency looks like! (letöltve: 2017.04.11)

https://www.cloos.de/de-en/processes/details/ rapid-weld/

[5] Biszku G.: Vastaglemezek hegesztése. Miskolci Egyetem. (letöltve: 2017.04.11)

http://docplayer.hu/15987490-Vastaglemezek-hegesztese.html/

[6] Kuti J.: Vastaglemez X varratos kötésének kiváltása szükített $V$ varrattal.

[7] Tóth L., Haraszti F., Kovács T.: A felületi érdesség hatása a hegesztett rozsdamentes acél korróziós ellenállására/Surface Roughness Effect in the Case of Welded Stainless Steel Corrosion Resistance. Acta Materialia Transylvanica 1/1. (2018) 53-56. https://doi.org/10.2478/amt-2018-0018 https://doi.org/10.2478/amt-2018-0017 